\title{
Seasonal changes in testosterone levels and androgen- dependent organs in male moles (Talpa europaea)
}

\author{
P. A. Racey \\ Department of Zoology, University of Aberdeen, Aberdeen AB9 2TN, U.K.
}

\begin{abstract}
Summary. Seasonal changes in testicular and plasma testosterone levels and in androgen-dependent organs were determined in moles breeding at $53^{\circ} \mathrm{N}$. Although the testes contain up to 30 times more testosterone during spermatogenesis than during sexual quiescence, appreciable quantities of this hormone are present during late summer and early autumn. Annual spermatogenesis lasts for only 2 months, but in some moles spermatozoa remain in the epididymis for up to 3 months after the testes have begun to involute, and may therefore be available to inseminate females coming into a second oestrus.
\end{abstract}

\section{Introduction}

The mole (Talpa europaea) is unusual among European mammals because of its short testicular cycle. Previous studies of the reproductive cycle in male moles, such as those of Allanson (1963), Deanesly \& Allanson (1967) and Godfrey \& Crowcroft (1960), have been restricted to analysis of weight changes of the testes and prostate glands. Seasonal changes in the fine structure of the epididymis and Leydig cells have been studied by Suzuki \& Racey $(1976,1978)$ and the present investigation of seasonal changes in plasma and testicular testosterone levels and in androgen-dependent organs was carried out concurrently. An illustrated account of the reproductive organs, which was called for by Godfrey \& Crowcroft (1960), is also provided.

\section{Materials and Methods}

Male moles (51) were caught at intervals of 4-6 weeks throughout 1 year in the vicinity of Stallmine, Lancashire, England $\left(53^{\circ} 54^{\prime} \mathrm{N} 2^{\circ} 57^{\prime} \mathrm{W}\right)$. They were taken to the Unit of Reproductive Biology, Liverpool, and immediately killed by decapitation. Blood was collected from the severed neck into heparinized tubes and centrifuged: the plasma was removed and stored at $-20^{\circ} \mathrm{C}$. The moles were then weighed, and the testes, epididymides, prostate, Cowper's, adrenal, pituitary and preputial glands were dissected out, weighed and frozen at $-20^{\circ} \mathrm{C}$. Prostatic secretions were blotted before the gland was weighed. From some animals, one epididymis and a piece of testis was taken for electron microscopy (Suzuki \& Racey, 1976, 1978). An additional piece of testis and some preputial glands were fixed in Bouin's fluid, embedded in paraffin wax, sectioned at $6 \mu \mathrm{m}$ and stained with haematoxylin and eosin (testis) or Masson's trichrome. Two diameters were measured in cross-sections of 10 seminiferous tubules for each individual. The relative abundance of the Leydig cells was scored throughout the year to facilitate comparison with the classification proposed by Fawcett, Neaves \& Flores (1973).

Spermatozoa from one epididymis were examined immediately after death by phase-contrast microscopy and their index of motility scored according to the scale of Emmens (1947) which runs from $0-4$. Some spermatozoa were stained for $2 \mathrm{~min}$ in a buffered solution of nigrosin-eosin on glass slides (Blackshaw, 1958) and then smeared. With an oil-immersion lens, the heads of 200 spermatozoa per mole were assessed for eosin penetration and eosinophilic spermatozoa were assumed to be dead at the time of staining.

Frozen epididymides were homogenized in distilled water, the homogenate made up to 200 or 400 $\mathrm{ml}$ depending on sperm density and the numbers of spermatozoa counted with a haemocytometer. 


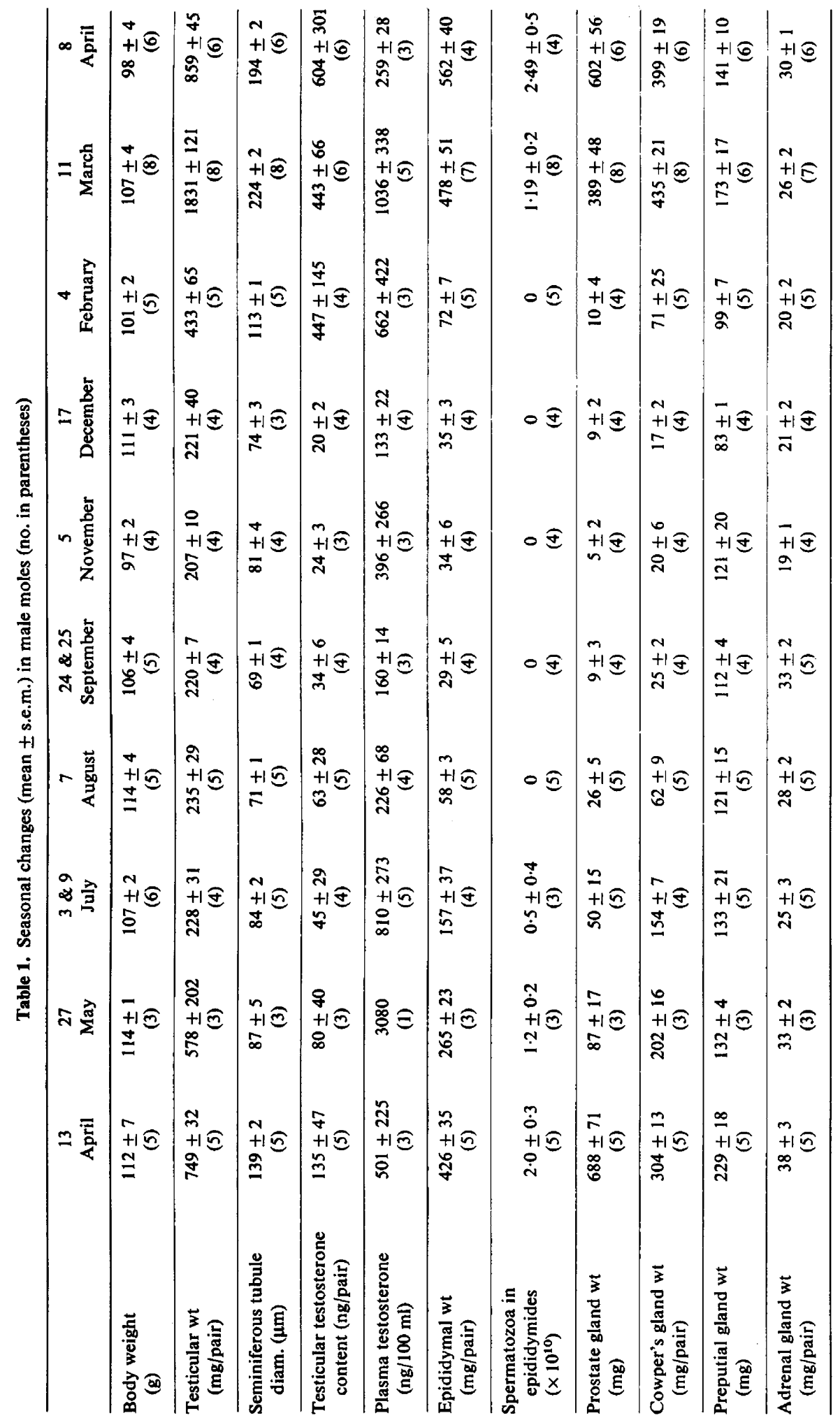




\section{PLATE 1}
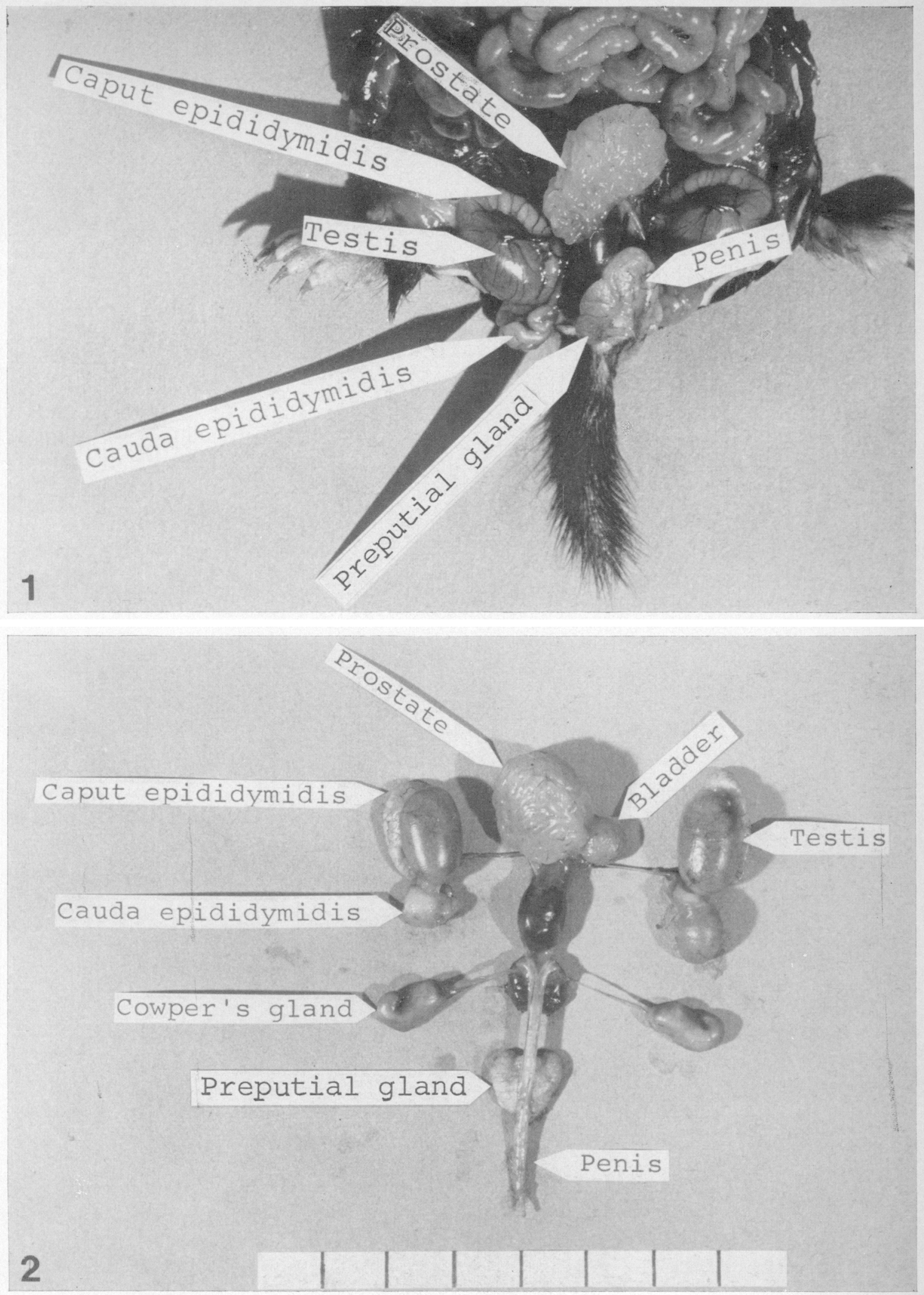

The reproductive organs of the male mole in situ (Fig. 1) and after dissection (Fig. 2). Cm scale. 
Testosterone was extracted from the testes by the method of Mann, Rowson, Short \& Skinner (1967), incorporating thin-layer chromatography on silica gel, and from the blood by the method of Rowe et al. (1974). Testosterone was determined in duplicate samples by the radioimmunoassay of Rowe et al. (1974) with an antibody raised to testosterone linked through the 3-keto group to bovine serum albumin. It showed a $27 \%$ cross-reaction with dihydrotestosterone but less than $0.1 \%$ with any other steroid tested. Dextran-coated charcoal was used to separate free from bound testosterone. The assay is sensitive to $50 \mathrm{pg}$. Intra-assay coefficients of variation were $14 \%$ at $122 \mathrm{pg}$ and $3 \%$ at $481 \mathrm{pg}$. Inter-assay coefficients of variation were $15 \%$ at $109 \mathrm{pg}$ and $10 \%$ at $460 \mathrm{pg}$. The accuracy of the assay was $104 \%$ at $250 \mathrm{pg}$ and $107 \%$ at $500 \mathrm{pg}$.

\section{Results}

All the moles in the study were considered to be adult except for one, caught in July, which weighed $111 \mathrm{~g}$ but had not reached puberty and was therefore excluded from the data. The results are detailed in Table 1 and the trends of some of the changes are summarized in Text-fig. 1.
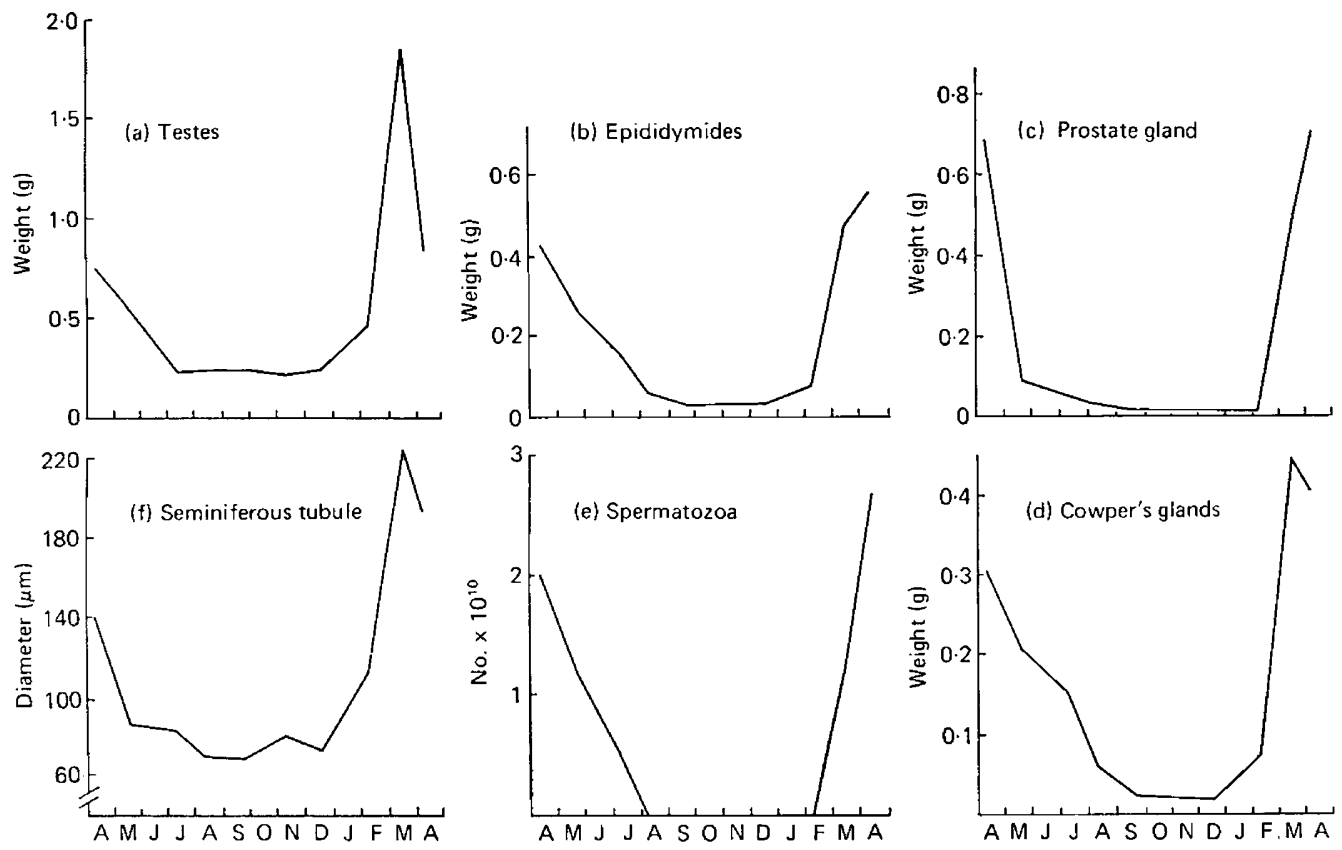

Text-fig. 1. Summary figure of the seasonal changes (see Table 1) in the weights of the paired testes (a), paired epididymides (b), prostate gland (c) and Cowper's glands (d), and the numbers of epididymal spermatozoa (e) and the seminiferous tubule diameter (f).

Body weight. The weight of the moles fluctuated throughout the year and varied considerably between individuals. There was, however, a marked fall from the peak in August throughout autumn.

Testis. The testes are situated in cremasteric sacs near the base of the tail (Pl. 1, Fig. 1), but do not cause any external swelling. Testicular weight was low throughout summer and autumn. A slight increase in weight was apparent in February and was followed by an abrupt increase to maximum weight in March. The weight loss during April was as rapid as the increase, but thereafter regression slowed, until minimal weight was reached in June. That these weight changes are accounted for by the rapid progress of spermatogenesis is shown by the close correlation with the changes in seminiferous tubule diameter (Text-fig. 1). 
The content of testosterone in the testes fell progressively to reach its lowest level in December and then rose rapidly when spermatogenesis began. High levels were maintained for 3 months, the highest individual value being recorded in April after regression of testicular weight and seminiferous tubule diameter was well advanced. The fall during spring and summer was slow, appreciable quantities of testosterone still being present in September. The plasma concentration of the hormone varied between $75 \mathrm{ng} / 100 \mathrm{ml}$ in December and $3080 \mathrm{ng} / 100 \mathrm{ml}$ in May. Mean levels rose with those in the testes during the progress of spermatogenesis but were much more variable outside the breeding season, with high values being recorded in July and November.

The size and ultrastructure of the Leydig cells varied little throughout the year (see Suzuki \& Racey, 1978). In sexually quiescent moles, the abundant and closely packed Leydig cells occupied nearly all the intertubular area and consequently most of the testis (Fawcett et al., 1973: type 3). These large areas of Leydig cells became separated into smaller clusters by the expansion of the seminiferous tubules during spermatogenesis (Fawcett et al., 1973: type 2).

Epididymides. A slight rise in the weight of the paired epididymides was recorded in February, followed by an abrupt rise in March and April as the epididymides filled with spermatozoa (Text-fig. 1). Thereafter, there was a steady decrease to minimal weight in September. Spermatozoa first appeared in the epididymides in March and large numbers were still present in the terminal segments of the epididymides of some individuals examined in July.

The percentage of epididymal spermatozoa stained with eosin was not $<15 \%$ in March, April and July, although in one individual examined in May it was $45 \%$. The index of motility of spermatozoa from the terminal segment of the epididymis varied between 1 and 4 on the Emmens' (1947) scale in March, April and May, but was $<1$ in July. Morphological defects such as misshapen acrosomes and bent tails were also seen in some individuals during July.

Accessory sex glands. The prostate is the only accessory sex gland present in the abdominal cavity (Pl. 1, Figs 1 and 2). The abrupt weight increase in March was maintained for 2 months and then followed by an equally abrupt decline (Text-fig. 1). The weight increase of the Cowper's glands was slight in February, but was followed by a more abrupt increase and a slower decline than for the prostate (Text-fig. 1). Changes in weight of the preputial gland were less well marked than those of the other reproductive organs, but there was nevertheless a significant elevation during the breeding season (Table 1 -December compared with March, $P<0.001$ ). At this time, the fur on the lower abdomen was covered with a pungent brown secretion which was also apparent under the chin. Both secretions had an odour similar to that of the dissected preputial gland. Histological examination showed that the preputial gland was a mixed holocrine and apocrine sebaceous gland.

Adrenal glands. The weight changes of the adrenal glands were generally similar to those of the reproductive organs, declining after the breeding season to reach lowest levels in November.

\section{Discussion}

In the brevity of its testicular cycle, the European mole (subfamily Talpinae) resembles two New World talpids of the subfamily Scalopinae, Scalopus aquaticus (Conaway, 1959) and Parascalops breweri (Eadie, 1939). Seasonal changes in the testicular content of testosterone have been determined in the rock hyrax, which also has a brief breeding season in subtropical latitudes (Millar \& Glover, 1973), hares (Lincoln, 1974), noctule bats (Racey, 1974) and in red deer and roe deer (Lincoln, 1971; Short \& Mann, 1966). In all these species, the highest levels of testosterone are associated with spermatogenesis and mating, and testosterone falls to very low levels thereafter. Similar results have been obtained in the present study on moles, and the cycle of the testis and the accessory glands is characteristic of a monoestrous breeder. However, there has long been interest in the occurrence of a late or second oestrus in moles (see Godfrey \& Crowcroft, 1960): Godfrey (1956) describes females in pro-oestrus and oestrus during October in East Anglia. Occasional late litters have been recorded in August and September in England (Barrett-Hamilton, 1910; Suffern, 1964), in October in Germany (Becker, 1959), and during autumn in southern France (Peyre, 1968). The present results, together with those of Suzuki \& Racey (1976), show that some spermatozoa remain in the epididymis for up to 3 
months after the abrupt decline in testis weight recorded in April at $53^{\circ} \mathrm{N}$. Becker (1959) also reported motile epididymal spermatozoa in moles during October. It would appear, therefore, that although the mole is generally characterized by a very short period of spermatogenic activity, sufficient androgens are circulating in some individuals to maintain the fertility of spermatozoa stored in the epididymis. Such individuals may remain potent and able to inseminate females coming into a late or second oestrus.

The study of Suzuki \& Racey (1978) on the fine structure of the Leydig cells showed clearly that during the long period of sexual quiescence characteristics such as cell size, abundance and appearance of smooth endoplasmic reticulum (SER), lipid droplets and mitochondria were similar to those during sexual activity. The present study shows that during sexual quiescence the testis contains up to thirty times less testosterone than that present during sexual activity. The role of the SER in steroidogenesis has been reviewed by Christensen \& Gillim (1969), and its presence in cells has frequently been taken as an indicator of steroidogenesis. The fact that abundant SER in the Leydig cells of the mole is associated with widely different testosterone levels in the testes suggests that the relative abundance of this organelle does not reflect the degree of steroidogenesis.

The preputial gland of moles has not previously been described. In rodents, this gland is a source of odour involved in agonistic responses which increase in frequency with increasing androgenization of the opponent and increasing weight of the preputial glands (Clevedon Brown \& Williams, 1972). It seems likely that this also applies to moles, since they defend their tunnels against intruders (Godfrey \& Crowcroft, 1960) and an increase in androgen levels is associated with an increase in the weight of the preputial gland. In view of the close proximity of the stained and odoriferous ventral surface of the mole with the tunnel floor, it is inevitable that the latter will become marked with odour.

The time of initiation of breeding in moles appears to vary with latitude. In northern Italy the first recorded pregnancy occurred in mid-February and the last at the beginning of April (Balli, 1940). Most pregnancies occur in March in southern England (Deanesly \& Allanson, 1967), during March and April in Suffolk (Godfrey, 1956), during May in North Wales (Deanesly \& Allanson, 1967) and during May and June in Scotland (P. A. Racey, unpublished observations). Similar variation of testicular development with latitude is also recorded by these authors and suggests that photoperiod is the proximate cause of the reproductive cycle. Although moles are mainly subterranean mammals, they venture above ground more than is generally supposed (Morris, 1966). Their nests consist of grass and leaves carried down from the surface (Godfrey \& Crowcroft, 1960) and mole bones are frequently found in owl pellets (Southern, 1954). Behavioural studies have shown that moles can respond to some visual stimuli and learn a light-dark discrimination (Lund \& Lund, 1966) and it seems likely that they are able to perceive changes in daylength. Deanesly \& Allanson (1967) could find no correlation between food availability or soil temperature and the initiation of reproduction, and suggested that the heavier rainfall further north was responsible for later breeding, because early litters would be more affected by heavy rainfall. However, this selection pressure would only operate in conditions of exceptionally high rainfall when the water table rises to flood the breeding fortresses.

The first signs of activity of the gonadotrophic cells of the anterior pituitary gland (Herlant, 1959a, b) and the first signs of testicular activity are not seen before the winter solstice. Whether there is a rapid response to increasing daylength after this solstice, or a delayed response to decreasing daylength before it, remains to be discovered. Sexual activity coincides with an increase in the activity of the pineal gland, particularly in the number of paracrystalline structures synthesized by pinealocytes (Pevet \& Smith, 1975). In addition, the prolactin-secreting cells of the anterior pituitary gland undergo massive hypertrophy during spermatogenesis and achieve maximum development during the phase of testicular involution (Pieters \& Herlant, 1972). These changes may be important in the cessation of reproductive activity in moles.

This work was initiated in the Unit of Reproductive Biology, University of Liverpool, and completed in Aberdeen. I should like to thank Professor T. D. Glover for his interest and encouragement and the Ford Foundation for financial support. 


\section{References}

Allanson, M. (1963) The reproductive tract of prepubertal and mature male moles during the anoestrus. J. Endocr. 26, ix $-\mathrm{x}$.

Ball, A. (1940) Osservazioni biologiche su Talpa europaea L. Rev. Biol. 29, 35-54.

BarRetT-Hamilton, G.E.H. (1910) A History of British Mammals, Vol. 2. Gurney \& Jackson, London.

BECKER, K. (1959) Uber einen Spätwurf bei Talpa europaea (L.). Z. Saugetierk. 24, 93-95.

BLACKSHAW, A.W. (1958) The effects of glycerol on the super vital staining of spermatozoa. Aust. vet. J. 34, 71-76.

Christensen, A.K. \& Gillim, S.W. (1969) The correlation of fine structure and function in steroid secreting cells, with emphasis on those of the gonads. In The Gonads, pp. 415-488. Ed. K. W. McKerns. Appleton Century Crofts, New York.

Clevedon Brown, J. \& Williams, J.D. (1972) The rodent preputial gland. Mammal Review 2, 105-147.

Conaway, C.H. (1959) The reproductive cycle of the eastern mole. J. Mammal. 40, 180-194.

Deanesly, R. \& Allanson, M. (1967) Climate and breeding season in the mole Talpa europaea. In Effects of External Stimuli on Reproduction, pp. 7180. Eds G. E. W. Wolstenholme \& M. O'Connor. (Ciba Fndn Study Group No. 26.) Churchill, London

EADIE, W.R. (1939) A contribution to the biology of Parascalops breweri. J. Mammal. 20, 150-173.

EMMENS, C.W. (1947) The motility and viability of rabbit spermatozoa at different hydrogen ion concentrations. J. Physiol., Lond. 106, 471-481.

Fawcett, D.W., Neaves, W.B. \& Flores, M.N. (1973) Comparative observations on intertubular lymphatics and the organization of the interstitial tissue of the mammalian testis. Biol. Reprod. 9, 500-532.

GoDFREY, G.K. (1956) Reproduction of Talpa europaea in Suffolk. J. Mammal. 37, 438-440.

Godfrey, G.K. \& CrowCroft, P. (1960) The Life of the Mole. Museum Press, London.

HerLant, M. (1959a) L'hypophyse de la Taupe au cours de la phase d'activité sexuelle. C. r. hebd. Séanc. Acad. Sci., Paris 248, 1033-1036.

Herlant, M. (1959b) Les modifications chez la Taupe. au cours de la phase d'activité sexuelle. C.r. Ass. Anat 46, 347-354.

LincolN, G.A. (1971) The seasonal reproductive changes in the red deer stag (Cervus elaphus). J. Zool., Lond. 163, 105-123.

LincolN, G.A. (1974) Reproduction and "Marchmadness" in the brown hare Lepus europaeus. J. Zool., Lond. 174, 1-14.
LUND, R.D. \& LuND, J.S. (1966) The central visual pathways and their functional significance in the mole (Talpa europaea). J. Zool., Lond. 149, 95-101.

Mann, T., Rowson, L.E.A., Short, R.V. \& Skinner, J.D. (1967) The relationship between nutrition and androgenic activity in pubescent twin calves, and the effect of orchitis. $J$. Endocr. 38, 455-468.

Millar, R.P. \& Glover, T.D. (1973) Regulation of seasonal sexual activity in an ascrotal mammal, the rock hyrax, Procavia capensis.J. Reprod. Fert., Suppl. 19, 203-220.

Morris, P. (1966) The mole as a surface dweller. J. Zool., Lond. 149, 46-49.

Pevet, P. \& Smith, A.R. (1975) The pineal gland of the mole (Talpa europaea L. ). II. Ultrastructural variations observed in the pinealocytes during different parts of the sexual cycle. J. neural Transmiss. 36, 227248.

Peyre, A. (1968) Cycles génitaux et corrélations hypophysogénitales chez trois insectivores européens. In Cycles Génitaux Saisonniers de Mammifères Sauvages, pp. 133-142. Ed. R. Canivenc. Masson, Paris.

Pieters, A. \& Herlant, M. (1972) Modifications saisonnières des cellules à prolactine dans l'antéhypophyse de la Taupe mâle. C. r. hebd. Séanc. Acad. Sci., Paris 274, 3002-3006.

RACEY, P.A. (1974) The reproductive cycle in male noctule bats, Nyctalus noctula. J. Reprod. Fert. 41, 169-182.

Rowe, P.H., Lincoln, G.A., Racey, P.A., Lehane, J., Stephenson, M.J., Shenton, J.C. \& Glover, T.D. (1974) Temporal variations of testosterone levels in the peripheral blood plasma of men. J. Endocr. 61, 63-73.

SHORT, R.V. \& MANN, T. (1966) The sexual cycle of a sesasonally breeding mammal, the roebuck (Capreolus capreolus). J. Reprod. Fert. 12, 337-351.

SOUTHERN, H.N. (1954) Tawny owls and their prey. Ibis 96, 384-410.

Suffern, C. (1964) A late litter of moles. The Mammal Society of the British Isles. Bulletin No. 21, p. 13.

SuZUKI, F. \& RACEY, P.A. (1976) Fine structural changes in the epididymal epithelium of moles (Talpa europaea) throughout the year. J. Reprod. Fert. 47, 47-54.

SuzUKI, F. \& RACEY, P.A. (1978) The organization of testicular interstitial tissue and changes in the fine structure of the Leydig cells of European moles (Talpa europaea) throughout the year. J. Reprod. Fert. 52, 189-194. 